\title{
CULM ANATOMY OF BOUTELOUA AND RELATIVES (GRAMINEAE: CHLORIDOIDEAE: BOUTELOUINAE)
}

\author{
Ma. Elena Siqueiros-Delgado \\ Universidad Autónoma de Aguascalientes \\ Centro de Ciencias Básicas, Departamento de Biología, \\ Av. Universidad 940, 20100 Aguascalientes, México \\ masiquei@correo.uaa.mx
}

\begin{abstract}
Transverse sections of mature flowering culms of Boutelouinae were analyzed to explore the usefulness of the culm anatomy to assess phylogenetic relationships. Fifty-five taxa were surveyed from the field and greenhouse collections. Although leaf anatomy in Boutelouinae has been shown to possess systematic utility, culm anatomy has been very little explored. In the Boutelouinae, only few traits of the culm middle internodal region with phylogenetic value, were found. Kranz structures (cells and radial chlorenchyma), number and position of the vascular bundles, and sclerenchyma girders are some culm anatomy characters that can be useful for inferring relationships at higher levels (family, tribes, genera). Culm anatomy suggests close relationships between B. eriopoda and $B$. eriostachya, and between $B$. ramosa and B. breviseta, and supports the inclusion of the satellite genera into Bouteloua. The Kranz structures and chloroplast shape appear to be the most variable features of this region of the culm.
\end{abstract}

Key words: anatomy, Bouteloua, culm, Gramineae.

\section{RESUMEN}

Se analizaron cortes transversales de la región media del tallo de 55 taxa de Boutelouinae, con el fin de explorar la utilidad de sus caracteres en el conocimiento de las relaciones filogenéticas del grupo. A pesar de que los caracteres anatómicos de hoja han mostrado ser útiles para inferir relaciones filogenéticas, el examen microscópico del culmo no revela la existencia de muchos rasgos informativos del aspecto evolutivo. Atributos como las estructuras Kranz, el número y posición de los haces vasculares y los anillos de esclerénquima pueden ser caracteres útiles para inferir relaciones filogenéticas a nivel de familia, tribu o género. La anatomía de tallo sugiere una estrecha relación entre B. eriopoda 
y B. eriostachya, así como entre B. ramosa y B. breviseta, además apoya la inclusión de los géneros satélites dentro de Bouteloua. Las estructuras Kranz y la forma de los cloroplastos parecen ser los caracteres mas variables de esta región del tallo.

Palabras clave: anatomía, Bouteloua, culmo, Gramineae.

\section{INTRODUCTION}

Boutelouineae (Gramineae: Chloridoideae) comprise seven genera: Aegopogon, Bouteloua, Hilaria, Melanocenchrus, Neobouteloua, Pleuraphis, and Schaffnerella (Columbus, 1999a). This subtribe is characterized by one or more non-digitate inflorescence branches, usually one or more reduced florets, and three-nerved lemmas, each nerve usually terminating in a lobe and/or awn (Columbus, 1996), and its culm anatomy corresponds to the Chloridoideae type (Auquier and Somers, 1967). Most representatives of Boutelouinae are natives of American grasslands (except Melanocenchrus from Africa), typically occur in arid or semiarid environments, and their value as forage grass is remarkable. Boutelouinae possess $\mathrm{C}_{4}$ photosynthesis pathway with the associated characteristic Kranz anatomy (Hattersley and Watson, 1975). Most Boutelouinae have NAD-ME (nicotinamide adenine dinucleotide co-factor to malic enzyme) biochemial pathway, characterized by XyMS+ (mestome present), centripetal chloroplast with granna, an even Kranz bundle sheath outline and suberised lamella. Some taxa, however, posses PCK (phosphoenolpyruvate carboxykinase), characterized by XyMS+ and centrifugal chloroplasts with granna and an uneven outline. XyMS+ are structural traits characteristic of arid conditions (Prendergast et al., 1987).

Bouteloua is the largest genus with 57 species (Columbus, 1999a), followed by Hilaria (9), Aegopogon (3), Melanocenchrus (3), Neobouteloua (1), Pleuraphis (3), and Schaffnerella (1) (Clayton and Renvoize, 1989). Gould (1980), based on morphology and cytology, recognized 39 species in two subgenera, Bouteloua and Chondrosium. Based on molecular evidence, Columbus et al. $(1998,2000)$ and Columbus (1999a), redefined the genus showing that the two subgenera are not monophyletic, and including into Bouteloua most of its diclinous relatives $\mathrm{Bu}$ chloë, Buchlomimus, Cathestecum, Cyclostachya, Griffitsochloa, Opizia, Pentarrhaphis, Pringleochloa and Soderstromia), rendering the genus as monophyletic. These satellite genera were segregated because of their diclinous reproductive system (Reeder, 1969). However, molecular data show that they are members of the Bouteloua clade. 
Leaf anatomy has proved to be a good phylogenetic tool for grass systematics. Many researchers have succeeded in using leaf anatomy to circumscribe species and infer phylogenies (Breakwell, 1914; Brown, 1958, 1975, 1977; Cerros-Tlatilpa, 1999; Columbus, 1996; Ellis, 1987; Fisher, 1939; Morden and Hatch, 1987; Sánchez, 1971). Columbus (1996) evidences the usefulness of leaf anatomy to infer phylogenies in the subtribe Boutelouinae. Based on micromorphology and leaf blade anatomy, he proposed the non-monophyly of Bouteloua and Chondrosium, the exclusion of $B$. juncea from the Bouteloua curtipendula complex, and the close relationship between B. eriopoda and B. aristidoides, which later were supported by molecular data (Columbus et al., 1998; Columbus et al., 2000; Siqueiros, 2001).

Except in bamboos (Agrasar and Rodríguez, 2002; Grosor and Liese, 1971; Liese 1980, 1998; Londoño et al., 2002; Sekar and Balasubramanian, 1994; Yao et al., 2002), culm anatomy in grasses, has been little explored regarding to the usefulness of its characters in phylogenetics (Cenci et al., 1984; Gasser et al., 1994; Ramos et al., 2002; Siqueiros and Herrera, 1996). Ramos et al. (2002) found that the most important variations in the culm components in Bromus aleuticus Trin. ex Ness are the cortical and medular parenchyma, the development and position of the vascular bundles, and the development of the sclerenchyma ring associated with these bundles. Siqueiros and Herrera (1996) found similar results, and pointed out that culm anatomy at the epinodal culm region in Bouteloua has restricted phylogenetic value. In Dasyochoa, Blepharidachne, and Munroa, however, culm anatomy has shown to be useful to differentiate groups at subfamily or tribal rank (Sánchez, 1983a, 1983b, 1984). In Boutelouinae, culm anatomy corresponds to Chloridoideae type (Auquier and Somers, 1967), and according to De Wet (1960) and Metcalfe (1960), its value in phylogenetics is limited.

Some anatomical characters that have been used in phylogenetic studies are: Kranz sheath (vascular bundle outer sheath), patterns in vascular bundles (CerrosTlatilpa, 1999; Columbus, 1996), sclerenchyma patterns (Siqueiros and Herrera, 1996), position and form of the chloroplasts (Columbus, 1996), shape and position of bulliform cells (Cerros-Tlatilpa, 1999; Columbus, 1996). Columbus (1996) pointed out that Kranz sheath is the most useful leaf anatomical character to infer common ancestry in Boutelouinae. In culm anatomy, however, the Kranz cells do not form an outer sheath as in the leaf. The bundle sheath is incomplete, forming an arc external to the vascular bundles. Kranz arc, radial chlorenchyma, culm outline, and chloroplast shape and position, are some of the culm anatomical features suggested to be useful for inferring phylogenies (Siqueiros and Herrera, 1996). 
The goal in this study was to characterize the culm anatomy of Bouteloua and relatives and to determine its value in phylogenetics.

\section{MATERIALS AND METHODS}

Transverse sections of mature flowering culms were obtained from the middle part of the first internode below the inflorescence. This region is usually devoid of leaf sheath. Samples were obtained from plants collected directly in the field or in the RSABG greenhouse. Most field collections were provided by J. T. Columbus, therefore, his collection number is indicated, unless otherwise. Four genera, including 55 taxa within Boutelouinae were surveyed. In addition, permanent slides from the epinodal culm region (above the node) of 49 taxa of Boutelouinae were surveyed in order to examine the chloroplast shape in young tissues. Mature tissue slides of Bouteloua dactyloides, B. johnstonii, B. megapotamica, B. vaneedenii, Melanocenchrus spp., Neobouteloua spp., and Schaffnerella gracilis were not obtained due to collecting and technical difficulties. For widely distributed species three or more samples from different geographical locations were studied, while for endemic or restricted taxa such as $B$. pedicellata, and $B$. reflexa, only one sample was studied (Appendix).

Samples were fixed in FPA and desilicificated with hydroxyfluoric acid. Tissues were dehydrated in ethanol series of 2 hs each (Ruzin, 1993) and embedded in paraplast. Before sectioning, the blocks were exposed and soaked in softening solution (Schmid and Turner, 1977), then rinsed in acetic acid. The tissues were sectioned and stained following Sharman (1943) protocol. The slides and the specimens are deposited at Rancho Santa Ana Botanic Garden, Claremont CA. Analyzed characters are shown in Table 1.

\section{RESULTS}

The analyses of the middle internode region of the flowering mature culms show a similar anatomical pattern in most Boutelouinae. However, variation among some taxa was observed. A brief description of the tissues and their position in the culm, the anatomical patterns of the genera, and the relationships among taxa inferred from culm anatomy is provided. 
Table 1. Culm anatomy characters analyzed in this study.

\begin{tabular}{|l|l|}
\hline Transection outline & Smooth, undulate \\
\hline Epidermic cells & $\begin{array}{l}\text { Presence/absence of cuticule } \\
\text { Presence/absence of silica cells }\end{array}$ \\
\hline Sclerenchyma patterns & $\begin{array}{l}\text { Forming a girder/not forming a girder } \\
\text { Forming a ring }\end{array}$ \\
\hline Kranz structures & $\begin{array}{l}\text { Shape and position of radial chlorenchyma } \\
\text { Shape of the Kranz arc: straight, horseshoe, or half circle } \\
\text { Number, shape, and position of Kranz cells } \\
\text { Shape and position of Kranz cells chloroplasts }\end{array}$ \\
\hline Mestome & $\begin{array}{l}\text { Number of mestome layers } \\
\text { Thickness of mestoma cell walls }\end{array}$ \\
\hline Vascular bundles & $\begin{array}{l}\text { Kind of vascular bundles: } \text { I }^{\circ}, \mathrm{II}^{\mathrm{o}}, \text { or III } \\
\text { Position } \\
\text { Number }\end{array}$ \\
\hline
\end{tabular}

Tissues description in Boutelouinae

Epidermis. The single-layered epidermis is composed of round to square cells surrounded by a cutin layer. Trichomes, stomata and silica bodies are usually present (Fig. 1E).

Sclerenchyma. Cells with thick secondary walls and a small lumen, are observed. They form a subepidermal ring variable in thickness (Fig. 1sR), and interrupted by peripheral vascular bundles (PVB). In cross-section outline, sclerenchyma forms a girder, usually yielding conspicuous crests (Fig. 1SG).

Parenchyma. Parenchymatous cells are thin walled, and can be tubular or isodiametric, forming the radial chlorenchyma and the culm pith. Radial chlorenchyma cells are usually small, tubular, and perpendicular to the epidermis surface, following the curvature of the Kranz arc (Fig. 1RCH). The culm pith is located in the center of the culm, and it is constituted by large, isodiametric, thin walled, rounded cells (Fig. 2). Sometimes internal vascular bundles (IVB) are embedded within the pith.

Kranz cells. In leaves, Kranz cells form a perivascular bundle sheath. However, in culms this bundle sheath is incomplete, giving an aspect of arc or crown, variable in size and number of cells. This incomplete bundle sheath is called Kranz arc (Fig.1KA). Kranz arc curvature varies from almost straight (Fig. 6KA) to half circle (Figs. 1, 4) or horseshoe (Fig. 7), always bordered by radial chlorenchyma. 

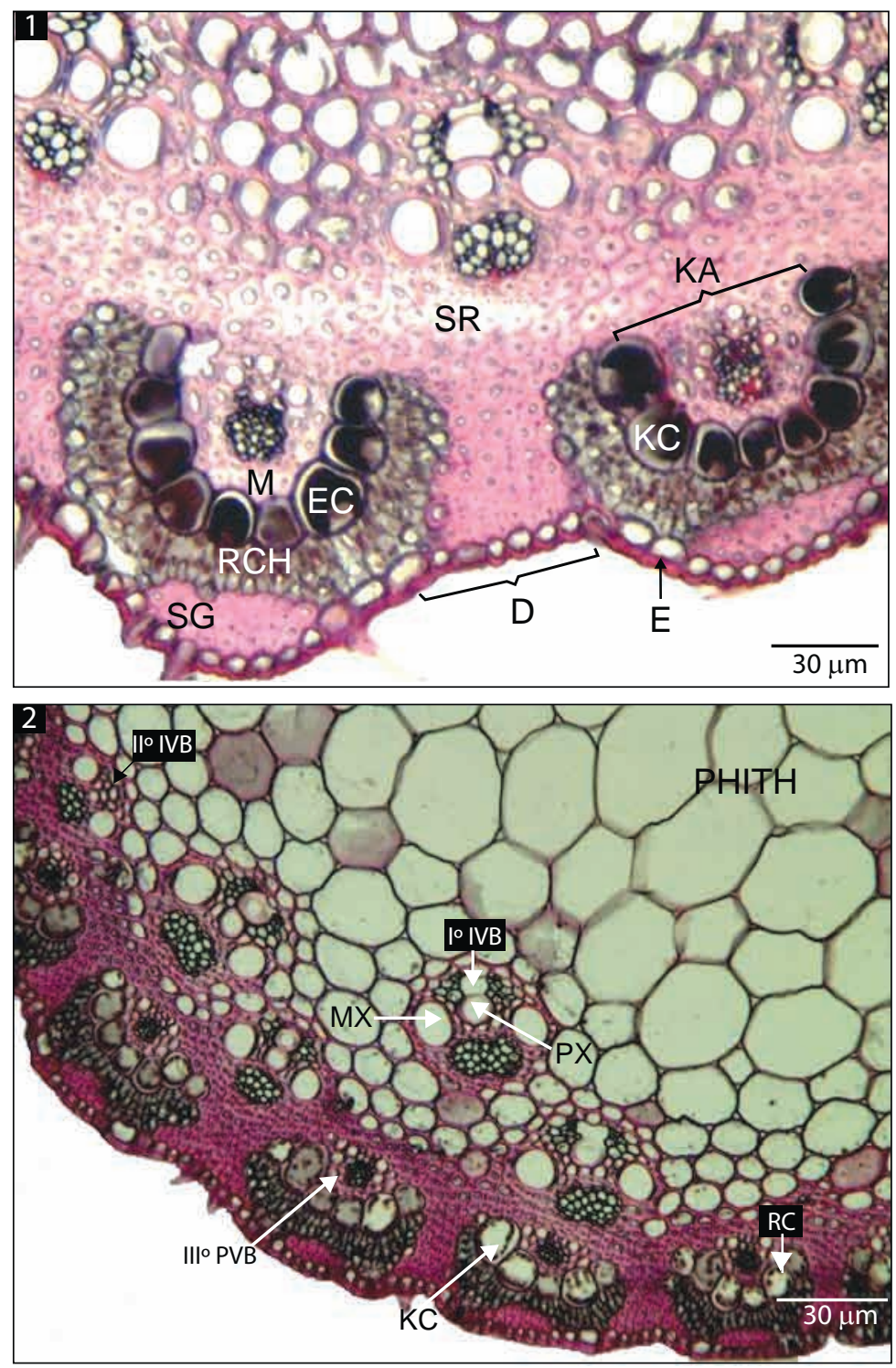

Figs. 1 y 2. Culm cross-section of Bouteloua chihuahuana (Columbus 2824), and B. curtipendula (Columbus 2573) showing some of the main features of the culm anatomy. D. Culm depressions. EC. Elongated centripetal chloroplasts. E. Epidermis. KA. Kranz arc. KC. Kranz cells. M. Mestome. MX. Metaxylem cells. PX. Protoxylem cells. RCH. Radial chlorenchyma. SR. Sclerenchyma ring. SG. Sclerenchyma girder. RC. Round centrifugal chloroplasts. I IVB. First order internal vascular bundles. $\mathrm{II}^{\circ} \mathrm{IVB}$. Second order internal vascular bundles. III ${ }^{\circ}$ PVB. Third order peripheral vascular bundles. 
Kranz cells may be regular to irregular, even to uneven, and their shape can vary from round to oval (Fig. 2KC), square or trapezoid (Fig.1 KC). The cells number is usually correlated with its size. According to our observations, Kranz cells are found only on the exposed mature zone of the internode and they hold elongate or round chloroplasts.

Mestome. It is formed by small, thick walled cells, similar to the sclerenchyma, surrounding the vascular bundles and occurring usually in a single layer. Mestome cells constitute the internal bundle sheath, and their size and shape are variable (Fig. 1M).

Vascular bundles. The vascular bundles are peripheral (PVB) or internal (IVB), and can be $\mathrm{I}^{\mathrm{o}}$ (proto and metaxylem cells well developed [Fig. 2MX, PX]), II $^{\circ}$ (only metaxylem cells developed), or III $^{\circ}$ (inconspicuous proto and metaxylem cells) order (Ellis, 1976; Fig. 2). The peripheral vascular bundles are associated to Kranz cells, and most of them are $\mathrm{III}^{\mathrm{o}}$ order. The IVB are $\mathrm{I}^{\circ}$ order or $\mathrm{II}^{\circ}$ order, and are organized in one to three concentric circles. The number of PVB, as well as IVB is variable.

Patterns of culm anatomy in Boutelouinae

Aegopogon. Culms are round to oval in cross-section, with a smoothly undulate outline (Fig. 3). Small and round epidermis cells are observed. The ones adjacent to radial chlorenchyma are larger than the rest of epidermis cells. Silica bodies and stomata are present. The sclerenchyma ring is formed by three to five layers of cells with evident lumen and surrounding 11 PVB in A. cenchroides, and one or none in A. tenellus. The Kranz arc is slightly curved with six to eight round, uneven cells with round chloroplasts. Sclerenchyma girder is missing. Seven to 17 IVB are embedded in the parenchymatous pith in two concentric circles, the outermost are $\mathrm{II}^{\mathrm{o}}$ and the internal ones are $\mathrm{I}^{\mathrm{o}}$ (Fig. 3).

Bouteloua. Culms are round to oval in cross-section, with a smooth to strongly undulate outline (Fig. 4). The epidermis cells usually are small, round, and regular to irregular. Some taxa, however, display larger, square, and regular cells (B. eriopoda [Fig. $5 \mathrm{E}]$ ). Trichomes, stomata and silica bodies are always present. The subepidermal zone displays a continuous sclerenchymatous ring (Fig. 6sR), 3 to 15 cells thick, interrupted by PVB with associated Kranz structures (Kranz cells and radial chlorenchyma). The sclerenchymatous ring completely surrounds the PVB and joins the IVB by their apexes. The PVB are usually $\mathrm{II}^{\circ}$ and their number ranges from 6 to 40. In undulated cross-sections PVB usually alternate with the culm de- 

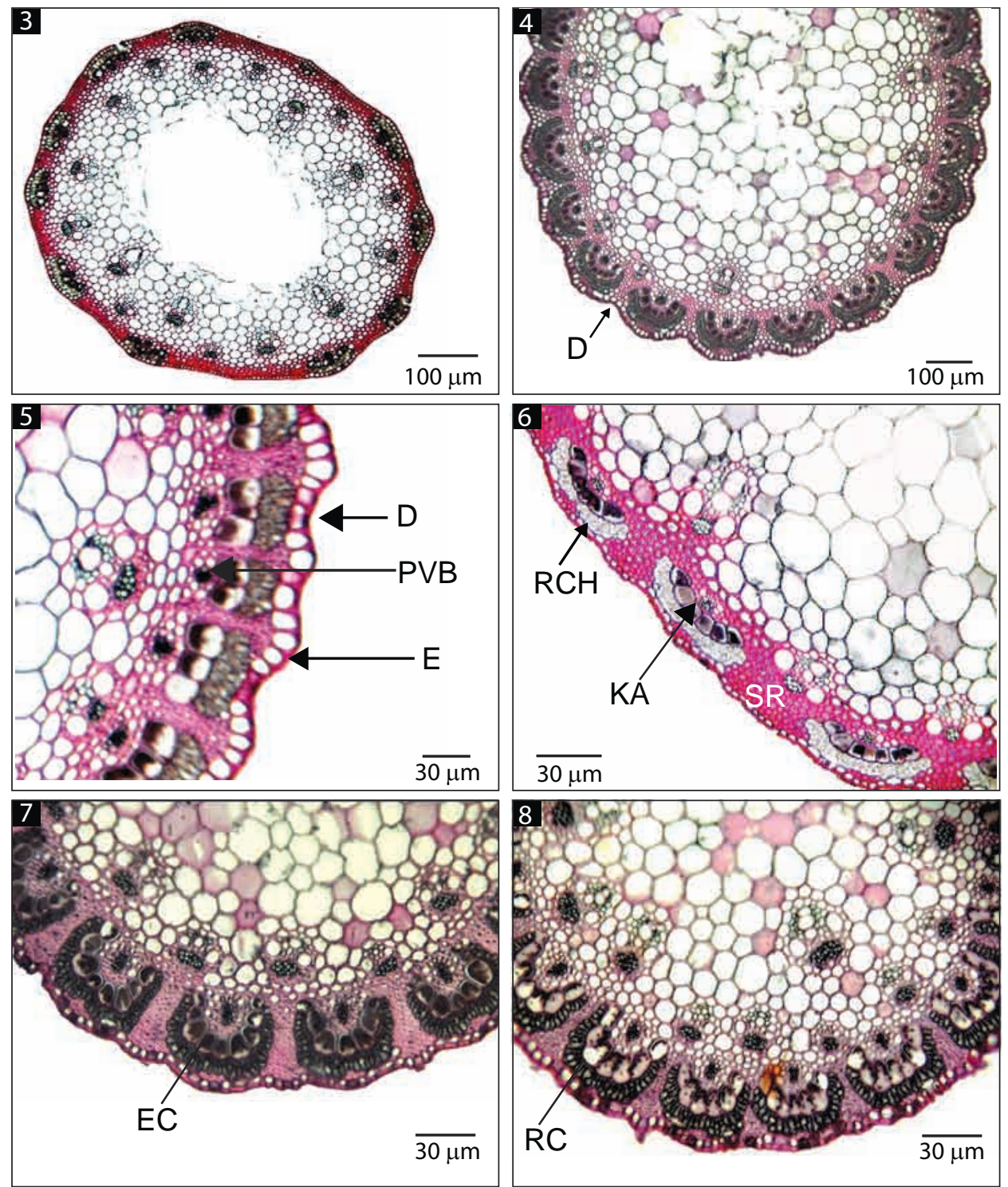

Figs. 3-8. Culm anatomy cross-sections of Aegopogon and Bouteloua, showing some features of the culm anatomy. Fig. 3. Aegopogon cenchroides (Columbus 2629). Fig. 4. Bouteloua hirsuta (Columbus 2713). Fig. 5. B. eriopoda (Columbus 2806). Fig. 6. B. quiriegoensis (Herrera \& Siqueiros 1320). Fig. 7. B. ramosa (Columbus 2486). Fig. 8. B. ramosa (Columbus 2807). D. Culm depressions. E. Epidermis. EC. Elongated centripetal chloroplasts. KA: Kranz arc. PVB. Third order peripheral vascular bundles. RC. Round centrifugal chloroplasts. RCH. Radial chlorenchyma. SR. Sclerenchyma ring. 
pressions (Fig. 4D), however, in B. eriopoda and B. eriostachya, PVB are opposite to culm depressions (Fig. 5D). Each PVB holds up an arc of Kranz cells of variable size, shape, curvature, and number. Some taxa show from 4 to 10 small, round, and uneven Kranz cells (B. curtipendula complex [Table 1, Fig. 2KC]); other show large square to oval, uniform cells (B. chihuahuana, B. eriopoda, B. hirsuta, and $B$. ramosa [Figs. $1 \mathrm{KC}, 5,4$, and 7, respectively]). The number of Kranz cells varies from 3 to 12 (usually 4 to 7 ), and the arc curvature varies from almost straight (B. aristidoides [Fig. 6KA] and the B. curtipendula complex taxa [Fig. 2]) to half circle (B. chihuahuana [Fig. 1KA], B. hirsuta [Fig. 4]), or horseshoe (B. ramosa [Fig. 7]). The chloroplasts of the Kranz cells are elongated (most Bouteloua taxa [Fig. 1EC, 7 $\mathrm{EC}, 11 \mathrm{EC}]$ ) or round (B. curtipendula complex [Fig. 2RC]). The radial chlorenchyma is variable in shape, always following the Kranz arc curvature (Fig. 1, 6RCH). Frequently, it possesses a depression in the central part, which is filled by the sclerenchyma girder (Fig. 1sG). The IVB vary from 12 to 40, and they are arranged in one to three concentric circles.

Hilaria. The culm is a half circle in cross-section, with a slightly to evidently undulated surface (Fig. 9). Small epidermal cells with thick cutin layer, silica cells, trichomes, and stomata are present. The sclerenchyma ring is formed by five layers of compact cells, surrounding eight to 13 PVB distributed mostly along the curved side. Kranz arc is slightly curved, formed by four to six round, uneven cells with round chloroplasts. Radial chlorenchyma is conspicuous, bordering the Kranz cells. Eleven to $17 \mathrm{I}^{\circ}$ order IVB in two concentric circles are found.

Pleuraphis. The culm is round to slightly oval, with an undulated margin in cross-section (Fig. 10). Epidermal cells are round and small. Silica cells, trichomes and stomata are present. Below the epidermis, there is a parenchyma ring of two or three layers (Fig. 10PR), interrupted by 17 to 24 PVB. Under the parenchyma ring, the sclerenchyma ring is located (Fig. 10SR). The Kranz arc is conspicuously curved in a half circle, with seven to eight squared, compact cells with elongate chloroplasts. Twenty-two I order IVB, in two concentric circles are found. The most external ones are attached on their apexes to the scherenchyma ring.

Relationships among taxa inferred by culm anatomy

Although culm anatomy characters have restricted value to infer phylogenetic relationships, several culm features may provide evidence of common ancestry. Most of the Boutelouinae taxa share a similar culm anatomy pattern. Undulated outline, sclerenchyma ring with PVB within, Kranz cells forming an arc, and IVB embed- 

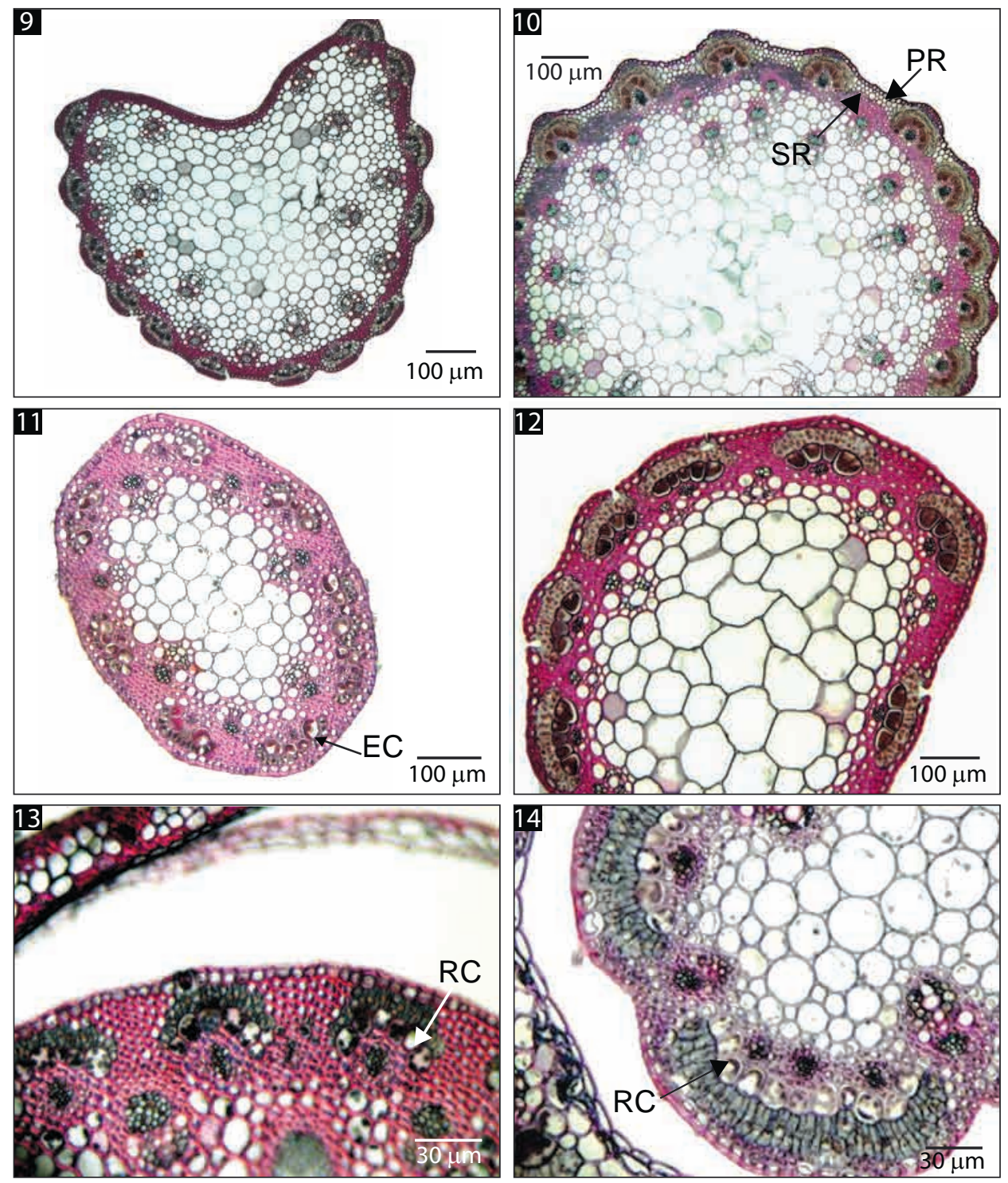

Figs. 9-14. Culm anatomy cross-section of Bouteloua, Hilaria and Pleuraphis showing some features of the culm anatomy. Fig. 9. Hilaria cenchroides (Columbus 2605). Fig. 10. Pleuraphis mutica (Columbus 2803). Fig. 11. Bouteloua juncea (Axelrod 8856). Fig. 12. $B$. aristidoides (Columbus 2801). Fig. 13. Immature culm cross-section of B. breviseta (Columbus 2280). Fig. 14. Immature culm cross-section of B. simplex (Columbus 2570). EC. Elongated centripetal chloroplasts. PR. Parenchyma ring. RC. Round centrifugal chloroplasts. SR: Sclerenchyma ring. 
ded in parenchymatic pith are the constant characters of this group (Fig. 1). Some related species, however, display few traits that allow inference of relationships. From all culm anatomy characters studied (Table 2), the Kranz structures (cells and radial chlorenchyma [Figs. 1KC, RCH]) and sclerenchyma ring (Fig. 1SR) apparently are the most useful. The Kranz cells, when mature, are the most conspicuous elements on the culm anatomy. The size, shape and uniformity of Kranz cells, the curvature the Kranz arc, the shape and size of radial chlorenchyma, the sclerenchyma girders and the position of sclerenchyma ring are the most variable traits. Also, the chloroplast shape of the Kranz cells may be an important trait for inferring relationships at higher taxonomical levels.

The taxa of the B. curtipendula complex display a pattern somewhat different from most of the remaining Boutelouinae. It shows a slightly curved Kranz arc with 4 to 8 round and irregular cells, and an inconspicuous to evident sclerenchyma girder (Fig. 2). However, the most compelling features that define the group is the presence of round, small, peripheral and centrifugal chloroplasts in the Kranz cells (Fig. 2RC). Centripetal chloroplasts are typical of NAD-ME type, and centrifugal ones are observed in NADP-ME type and some species of PCK type (Pendergast et al., 1987). Small, centrifugal chloroplasts plus other structural traits in leaves (suberized lamella, uneven bundle sheath) have been associated to PCK pathway of $\mathrm{C}_{4}$ photosynthesis (Hattersley and Watson, 1975). The PCK pathway has been documented in B. curtipendula (Gutiérrez et al., 1974; Prendergast et al., 1987), and in Hilaria belangeri (Brown, 1977). Chapman and Peat (1992) pointed out that B. curtipendula may have both PCK and NAD-ME $\mathrm{C}_{4}$ photosynthetic mechanisms, however, Prendergast et al. (1987) state that B. curtipendula, may be biochemically and structurally intermediate between NAD-ME/PCK, since this species, unlike the "classical" PCK species (Hattersley and Browning, 1981), lacks suberized lamella and uneven bundle sheath outline. It has been suggested that PCK type species evolved from NAD-ME type (Hattersely and Watson, 1992; and Clayton and Renvoize, 1989). Columbus et al. (1998, 2000), based on molecular data, showed that Aegopogon, Hilaria and B. curtipendula do not descend from the same most recent ancestor, suggesting that chloroplast shape evolved independently from different NAD-ME ancestors. Although it has not been previously proposed, the rest of the taxa of the B. curtipendula complex (Appendix) likely exhibit the same photosynthesis pathway, since they share the same chloroplast features.

Gould and Kapadia (1964) recognized 12 species in the B. curtipendula complex (Appendix). Columbus (1996) based on leaf anatomy and micromorphology, pointed out that B. juncea was not a member of the complex. Molecular data (Co- 
lumbus et al., 1998; Columbus et al., 2000; Siqueiros, 2001) further support the exclusion of B. juncea from the B. curtipendula complex. Elongated centripetal chloroplasts of the Kranz cells, supports the exclusion of $B$. juncea from the complex (Fig. 11EC).

Except taxa of the B. curtipendula complex, most Bouteloua species, typically display elongated centripetal chloroplasts in leaves and culms. Noteworthy is the presence of round, peripheral chloroplasts in the culm Kranz cells in B. americana (Worthington 22775), B. barbata (2289), B. breviseta (2280 [Fig. 13RC], 2908), B. dimorpha (2373, 2593, 2647), B. nervata (2343), B. radicosa (2341, 2462), B. ramosa (2807 [Fig. 8RC], 2846), B. repens (2332, 2425), B. simplex (2579 [Fig. 14RC]), and B. williamsii (2357), which typically display elongate and centripetal chloroplasts. Several populations of $B$. repens complex, sister group of $B$. curtipendula complex (Columbus et al., 1998), exhibit round chloroplasts, rather than elongated ones in culm Kranz cells. In fact, several taxa in Boutelouinae possess round chloroplasts in juvenile stages of culm development, while the culm Kranz cells are not well differentiated yet (Figs. 13, 14RC). This could indicate that round chloroplasts may be the ancestral shape in Boutelouinae, which later in their evolution have changed to elongate in the NAD-ME type in most taxa.

Bouteloua eriopoda and B. eriostachya share the same unique pattern, particularly with respect to the position of the PVB, which are opposite to the culm depressions. Also, the Kranz arc is nearly straight, formed by oval to rectangular and regular cells. The radial chlorenchyma is conspicuous, and lies along the upper surface of the arc, not bordering the sides of the ending cells, as found in the other taxa (Fig. 6). Anatomical, molecular, and morphological evidence (Columbus, 1996; Columbus et al., 1998; and Columbus, 1999b, respectively) show that B. eriopoda and B. eriostachya are closely related. In fact, Swallen (1939) recognized them as a single species.

Columbus et al. (1998) and Columbus (1999b), show evidence of a close relationship among B. eriopoda, B. eriostachya, B. annua and B. aristidoides. Similarities between B. eriopoda and B. eriostachya, and also between B. annua and $B$. aristidoides were found, but not between the two pairs of clades. The clade $B$. eriopoda-B. eriostachya differs from $B$. annua-B. aristidoides clade in the presence of highest number of PVB, the shape of radial chlorenchyma, and by the absence of sclerenchyma girder. Bouteloua aristidoides and B. quiriegoensis also share a similar pattern, with square and regular cells, forming nearly a straight arc (Figs. 6 and 12 , respectively). Bouteloua hirsuta displays similar features; however, it differs in 
its Kranz arc, which is conspicuously curved (Fig. 4). In the Boutelouinae phylogeny (Columbus et al., 1998, 2000), these taxa are closely related forming sister clades.

Bouteloua ramosa and B. breviseta share also similar features in culm anatomy, particularly with respect to Kranz structures. The most distinct feature characterizing these two species is an angular Kranz arc with large and elongated cells, bordered by an angular radial chlorenchyma (Fig. 7). Bouteloua ramosa differs in its horseshoe shaped arc, while B. breviseta has a less curved arc. Both also share round chloroplasts in immature developmental stages (Fig. 8, 13RC). Bouteloua ramosa and B. breviseta have been suggested to be closely related to B. chasei and $B$. karwinskii, however, the two latter do not exhibit the angular arc, and their Kranz cells are rounded but not elongated.

Culm anatomy also supports the inclusion of the satellite genera (Buchloë, Buchlomimus, Cathestecum, Cyclostachya, Griffitsochloa, Opizia, Pentarrhaphis, Pringleochloa and Soderstromia) within Bouteloua (Columbus, 1999a), as all of them posses almost the same basic anatomical pattern of Bouteloua.

\section{CONCLUSIONS}

Although culm anatomy does not display the same degree of variation as leaf anatomy does, there are several culm anatomy characters that can be useful for inferring relationships at higher levels (family, tribes, genera). The most important phylogenetic culm anatomy features are Kranz structures (cells and radial chlorenchyma), number and position of the vascular bundles, and sclerenchyma girders. Bouteloua eriopoda and B. eriostachya share similar anatomical structure, as B. breviseta and $B$. ramosa do. Culm anatomy also supports the inclusion of satellite genera in Bouteloua. In general culm anatomy has valuable, but a restricted systematic value.

\section{ACKNOWLEDGMENTS}

This study was funded by Rancho Santa Ana Botanic Garden. I thank J. Travis Columbus for his support, advice, and allowing me to use his plant material, J. Mark Porter kindly reviewed the first draft of this paper. Especially, I want to thank Rosa Cerros-Tlatilpa for her pertinent suggestions to the manuscript, for helping me with the pictures editing, and for her friendship. 


\section{LITERATURE CITED}

Agrasar, Z. E. R. D. and M. F. Rodríguez. 2002. Cauline anatomy of native woody bamboos in Argentina and neighboring areas: epidermis. Bot. J. Linn. Soc. 138(1): 45-55.

Auquier, P. and Y. Somers. 1967. Recherches histotaxonomiques sur le chaume des Poaceae. Bull. Soc. Roy. Bot. Belgique 100: 95-140.

Breakwell, E. 1914. A study of the leaf-anatomy of some native species of the genus Andropogon. Proc. Linn. Soc. New South Wales ser. 2, 39: 385-394.

Brown, W. V. 1958. Leaf anatomy in grass systematics. Bot. Gaz. 119: 170-178.

Brown, W. V. 1975. Variations in anatomy, associations, and origins of Kranz tissue. Amer. J. Bot. 62: 395-402.

Brown, W. V. 1977. The Kranz syndrome and its subtypes in grass systematics. Mem. Torr. Bot. Club 23: 1-97.

Cenci, C. A., S. Grando and S. Ceccarelli. 1984. Culm anatomy in barley (Hordeum vulgare). Can. J. Bot. 62: 2023-2027.

Cerros-Tlatilpa, R. 1999. Estudio sistemático del género Chloris Sw. en México. Tesis de Maestría en Ciencias. Facultad de Ciencias, Universidad Nacional Autónoma de México. México, D.F. 165 pp.

Chapman, G. P. and W. E. Peat. 1992. An introduction to the grasses (including bamboos and cereals). CAB International. Wallingfore. $111 \mathrm{pp}$.

Clayton, W. D. and S. A. Renvoize. 1989. Genera graminum-grasses of the world. Her Majesty's Stationary Office. London. 389 pp.

Columbus, J. T. 1996. Lemma micromorphology, leaf anatomy, and phylogenetics of Bouteloua, Hilaria, and relatives (Gramineae: Chloridoideae: Boutelouinae). Ph. D dissertation. University of California. Berkeley. 258 pp.

Columbus, J. T. 1999a. An expanded circumscription of Bouteloua (Gramineae: Chloridoideae): New combinations and names. Aliso 18(1): 61-65.

Columbus, J. T. 1999b. Morphology and leaf anatomy suggest a close relationship between Bouteloua aristidoides and B. (Chondrosium) eriopoda (Gramineae: Chloridoideae). Syst. Bot. 23(4): 467-478.

Columbus, J. T., M. S. Kinney, R. Pant and M. E. Siqueiros. 1998. Cladistic parsimony analysis of internal transcribed spacer region (nrDNA) sequences of Bouteloua and relatives (Gramineae: Chloridoideae). Aliso 7(2): 99-130.

Columbus, J. T., M. S. Kinney, M. E. Siqueiros and J. M. Porter. 2000. Phylogenetics of Bouteloua and relatives (Gramineae: Chloridoideae): Cladistic parsimony analysis of internal transcribed spacer (nrDNA) and trnL-F (cpDNA) sequences. In: Jacobs, S. W. L. and J. Everett (eds.). Grasses: systematics and evolution. CSIRO Publishing, Victoria. pp. 189-194.

De Wet, J. M. 1960. Culm anatomy in relation to taxonomy. Bothalia 7: 311.

Ellis, R. P. 1976. A procedure for standardizing comparative leaf anatomy in the Poaceae. I. The leaf-blade as viewed in transverse section. Bothalia 12: 65-109. 
Ellis, R. P. 1987. A review of comparative leaf blade anatomy in the systematics of the Poaceae: The past twenty-five years. In: Soderstrom, T. R., K. W. Hilu, C. S. Campbell and M. E. Barkworth (eds.). Grass systematics and evolution. Smithsonian Institution Press, Washington, D.C. pp. 3-10.

Fisher, B. S. 1939. A contribution to the leaf anatomy of Natal grasses, Series I: Chloris Sw., and Eustachys Desv. Ann. Natal Mus. 90: 245-267.

Gasser, M., A. C. Vegetti and J. A. Tivano. 1994. Anatomía de las estructuras foliares y caulinares en vástagos reproductivos de Eleusine indica (L.) Gaertner y E. tristachya (Lam.) Lam. Resúmenes VI Congreso Latinoamericano de Botánica. Mar del Plata. p. 39.

Gould, F. W. 1980. The genus Bouteloua (Poaceae). Ann. Mo. Bot. Gard. 66: 348-416.

Gould, F. W. and Z. J. Kapadia. 1964. Biosystematic studies in the Bouteloua curtipendula complex. II. Taxonomy. Brittonia 16: 182-207.

Grosor, D. and W. Liese. 1971. On the anatomy of Asian bamboos, with special reference to their vascular bundles. Wood Science and Technology 5: 290-312.

Gutiérrez, V. M., V. E. Gracen and G. E. Edwards. 1974. Biochemical and cytological relationships in $\mathrm{C}_{4}$ plants. Planta 119: 279-300.

Hattersley, P. W. and A. J. Browning. 1981. Ocurrence of the suberized lamella in leaves of grasses of different photosynthetic types. I. In parenchymatous bundle sheaths and PCR (“Kranz") sheaths. Protoplasma 109: 371-401.

Hattersley, P. W. and L. Watson. 1975. Anatomical parameters for predicting photosynthetic pathways of grass leaves: The "maximum lateral cell count" and the "maximum cell distant count". Phytomorph. 25: 225-333.

Hattersley, P. W. and L. Watson. 1992. Diversification of photosynthesis. In: Chapman, G. P. (ed.). Grass evolution and domestication. Cambridge Univ. Press, Cambridge. pp. 38-116.

Liese, W. 1980. Anatomy of bamboo. In: Lessard, G. and A. Chovinard (eds). Bamboo Research in Asia. Proceedings of a workshop held in Singapore. pp. 161-164.

Liese, W. 1998. The anatomy of bamboo culms. Technical Report 18. International Network for Bamboo and Rattan. Beijing. 204 pp.

Londoño, X., G. C. Camayo, N. M. Riaño and Y. López. 2002. Characterization of the anatomy of Guadua angustifolia (Poaceae: Bambusoideae) culms. J. Amer. Bamboo Soc. 16(1): 18-31.

Metcalf, C. R. 1960. Anatomy of the monocotyledons. I. Gramineae. Clarendon Press. Oxford. $731 \mathrm{pp}$.

Morden, C. W. and S. Hatch. 1987. Anatomical study of the Muhlenbergia repens complex (Poaceae: Chloridoideae: Eragrostoideae). Sida 12: 347-359.

Prendergast, H. D. V., P. W. Hattersley and N. E. Sotne. 1987. New structural/Biochemical associations in leaf blades of $\mathrm{C}_{4}$ grasses (Poaceae). Australian J. Plant Physiol. 14: 403-420.

Ramos, J. C., J. C. Tivano and A. C. Veguetti. 2002. Estudio anatómico de vástagos reproductivos en Bromus auleticus Trin. ex Nees (Poaceae). Gayana Bot. 59(2): 5160. 
Reeder, J. R. 1969. Las gramíneas dioicas de México. Bol. Soc. Bot. Méx. 30: 121-126.

Ruzin, S. 1993. Plant michrotechnique. NSF Center of Plant Development Biology, University of California. Berkeley. $82 \mathrm{pp}$.

Sánchez, E. 1971. Anatomía foliar de las Chloridoideae (Gramineae) argentinas. Kurtziana 6: 103-218.

Sánchez, E. 1983a. Estudios anatómicos en Blepharidachne Hackel (Poaceae, Eragrostidoideae, Eragrostae). Rev. Museo Arg. Cs. Nat. "Bernardino Rivadavia” 6(3): 73.

Sánchez, E. 1983b. Dasyochloa Willdenow ex Rydberg (Poaceae) género monotípico de Norteamérica. Lilloa 361-131.

Sánchez, E. 1984. Estudios anatómicos en el género Munroa (Poaceae, Chlorideae, Eragrostidae). Darwiniana 25(1-4): 43.

Schmid, R. and M. D. Turner. 1977. Contrad 70, an effective softener of herbarium material for anatomical study. Taxon 26: 551-552.

Sekar, T. and A. Balasubramanian. 1994. Culm anatomy of Guadua and its systematic position. BIC- India Bull. 4(1-2): 6-9.

Sharman, B. C. 1943. Tannic acid and iron alum with safranin and orange $G$ in studies of the shoot apex. Stain Technol. 3: 105-111.

Siqueiros, M. E. 2001. Phylogenetics of the Bouteloua curtipendula complex (Gramineae: Chloridoideae). Ph. D. dissertation. Claremont Graduate University. Claremont, CA. 141 pp.

Siqueiros, M. E. and Y. Herrera. 1996. Taxonomic value of the culm anatomical characters in the species of Bouteloua Lagasca (Poaceae: Eragrostoideae). Phytologia 81(2): 124-141.

Swallen, J. R. 1939. Chlorideae. North American Flora. Vol. 17. New York Botanical Garden. New York. pp. 579-638.

Yao, X., T. M. Yi, N. X. Ma, Y. F. Wang and Y. Li. 2002. Bamboo culm anatomy of China. Science Press. Beijing. 187 pp.

Recibido en diciembre de 2004. Aceptado en agosto de 2006. 
Appendix. Taxa, collections/vouchers, and origin of slides made for this study. Specimens and slides are deposited at RSA. *Denotes Bouteloua curtipendula complex representatives.

\begin{tabular}{|c|c|c|}
\hline Taxon & Collection/Voucher & Origin \\
\hline $\begin{array}{l}\text { Aegopogon cenchroides Humb. \& } \\
\text { Bonpl. ex Willd. }\end{array}$ & \begin{tabular}{|l} 
Columbus 2629 \\
Columbus 2740
\end{tabular} & $\begin{array}{l}\text { México: Michoacán } \\
\text { México: Sonora }\end{array}$ \\
\hline Aegopogon tenellus (DC.) Trin. & \begin{tabular}{|l} 
Columbus 2415 \\
Columbus 2720
\end{tabular} & $\begin{array}{l}\text { México: Oaxaca } \\
\text { México: Sonora }\end{array}$ \\
\hline $\begin{array}{l}\text { Bouteloua dactyloides (Nutt.) } \\
\text { J. T. Columbus }\end{array}$ & $\begin{array}{l}\text { Columbus } 2565 \\
\text { Columbus } 25689 \\
\text { Columbus } 2602\end{array}$ & $\begin{array}{l}\text { México: Hidalgo } \\
\text { México: Querétaro } \\
\text { México: San Luis Potosí }\end{array}$ \\
\hline Bouteloua alamosana Vasey & $\begin{array}{l}\text { Columbus } 2418 \\
\text { Herrera \& } \\
\text { Siqueiros } 1319\end{array}$ & $\begin{array}{l}\text { México: Oaxaca } \\
\text { México: Sonora }\end{array}$ \\
\hline Bouteloua annua Swallen & $\begin{array}{l}\text { Columbus } 2433 \\
\text { Columbus } 2434\end{array}$ & $\begin{array}{l}\text { México: Baja California Sur } \\
\text { México: Baja California Sur }\end{array}$ \\
\hline Bouteloua americana (L.) Scribn. & Worthington 22775 & Grenada: St. George \\
\hline $\begin{array}{l}\text { Bouteloua aristidoides (Kunth) } \\
\text { Griseb. }\end{array}$ & $\begin{array}{l}\text { Columbus } 2644 \\
\text { Columbus } 2692 \\
\text { Columbus } 2788 \\
\text { Columbus } 2801 \\
\end{array}$ & $\begin{array}{l}\text { México: Oaxaca } \\
\text { México: Sonora } \\
\text { México: Chihuahua } \\
\text { México: Chihuahua }\end{array}$ \\
\hline Bouteloua barbata Lag. & $\begin{array}{l}\text { Columbus } 2454 \\
\text { Columbus } 2646 \\
\text { Columbus } 2693 \\
\text { Columbus } 2799 \\
\text { Columbus } 2800 \\
\text { Columbus } 2811 \\
\text { Columbus } 2829 \\
\text { Columbus } 2837 \\
\text { Columbus } 2844 \\
\text { Columbus } 2576\end{array}$ & $\begin{array}{l}\text { U.S.A.: Arizona } \\
\text { México: Oaxaca } \\
\text { México: Sonora } \\
\text { México: Chihuahua } \\
\text { México: Chihuahua } \\
\text { México: Chihuahua } \\
\text { México: Durango } \\
\text { México: Coahuila } \\
\text { México: Coahuila } \\
\text { México: Hidalgo }\end{array}$ \\
\hline $\begin{array}{l}\text { Bouteloua bracteata (McVaugh) J. T. } \\
\text { Columbus }\end{array}$ & Columbus 2373 & México: Michoacán \\
\hline Bouteloua breviseta Vasey & $\begin{array}{l}\text { Columbus } 2530 \\
\text { Columbus } 2279 \\
\text { Columbus } 2280 \\
\text { Columbus } 2908\end{array}$ & $\begin{array}{l}\text { U.S.A.: Arizona } \\
\text { U.S.A.: Texas } \\
\text { México: Tamaulipas } \\
\text { U.S.A.: New Mexico }\end{array}$ \\
\hline Bouteloua chasei Swallen & Columbus 2328 & México: San Luis Potosí \\
\hline $\begin{array}{l}\text { Bouteloua chihuahuana (M. C. } \\
\text { Johnst.) J. T. Columbus }\end{array}$ & Columbus 2824 & México: Chihuahua \\
\hline $\begin{array}{l}\text { Bouteloua chondrosioides (Kunth) } \\
\text { Benth. ex S. Watson }\end{array}$ & \begin{tabular}{|l} 
Columbus 2451 \\
Columbus 2609 \\
Columbus 2622 \\
Columbus 2791
\end{tabular} & $\begin{array}{l}\text { U.S.A.: Arizona } \\
\text { México: Jalisco } \\
\text { México: Michoacán } \\
\text { México: Chihuahua }\end{array}$ \\
\hline
\end{tabular}


Appendix. Continuation

\begin{tabular}{|c|c|c|}
\hline \multirow[t]{2}{*}{ Taxon } & Collection/Voucher & Origin \\
\hline & $\begin{array}{l}\text { Herrera \& } \\
\text { Siqueiros } 1301\end{array}$ & México: Aguascalientes \\
\hline \multirow{24}{*}{$\begin{array}{l}\text { *Bouteloua curtipendula (Michx.) } \\
\text { Torr. }\end{array}$} & Columbus 2191 & México: Coahuila \\
\hline & Columbus 2124 & U.S.A.: Texas \\
\hline & Columbus 2213 & U.S.A.: New Mexico \\
\hline & Columbus 2331 & México: Hidalgo \\
\hline & Columbus 2449 & U.S.A.: Arizona \\
\hline & Columbus 2549 & México: México \\
\hline & Columbus 2572 & México: Hidalgo \\
\hline & Columbus 2573 & México: Hidalgo \\
\hline & Columbus 2574 & México: Sonora \\
\hline & Columbus 2592 & México: Querétaro \\
\hline & Columbus 2596 & México: San Luis Potosí \\
\hline & Columbus 2604 & México: San Luis Potosí \\
\hline & Columbus 2606 & México: San Luis Potosí \\
\hline & Columbus 2610 & México: Jalisco \\
\hline & Columbus 2620 & México: Michoacán \\
\hline & Columbus 2790 & México: Chihuahua \\
\hline & Columbus 2809 & México: Chihuahua \\
\hline & Columbus 2817 & México: Chihuahua \\
\hline & Columbus 2823 & México: Chihuahua \\
\hline & Columbus 2834 & México: Coahuila \\
\hline & Columbus 2845 & México: Coahuila \\
\hline & Columbus 2857 & México: Nuevo León \\
\hline & Columbus 2868 & México: Tamaulipas \\
\hline & $\begin{array}{l}\text { Herrera \& } \\
\text { Siqueiros } 1458\end{array}$ & México: Coahuila \\
\hline \multirow[t]{5}{*}{ Bouteloua dimorpha J. T. Columbus } & Columbus 2375 & México: Michoacán \\
\hline & Columbus 2589 & México: Querétaro \\
\hline & Columbus 2593 & México: Querétaro \\
\hline & Columbus 2633 & México: Puebla \\
\hline & Columbus 2647 & México: Puebla \\
\hline \multirow[t]{2}{*}{ *Bouteloua distans Swallen } & Siqueiros 4449 & México: Оахаса \\
\hline & Siqueiros 4454 & México: Puebla \\
\hline \multirow[t]{2}{*}{ *Bouteloua disticha (Kunth) Benth. } & Columbus 2376 & México: Michoacán \\
\hline & Columbus 2693 & México: Guerrero \\
\hline \multirow{3}{*}{$\begin{array}{l}\text { Bouteloua diversispicula } \\
\text { J. T. Columbus }\end{array}$} & Columbus 2598 & México: San Luis Potosí \\
\hline & Columbus 2694 & México: Sonora \\
\hline & Columbus 2904 & U.S.A.: Texas \\
\hline Bouteloua elata Reeder \& C. Reeder & Columbus 2358 & México: Jalisco \\
\hline
\end{tabular}


Appendix. Continuation

\begin{tabular}{|c|c|c|}
\hline Taxon & Collection/Voucher & Origin \\
\hline Bouteloua eludens Griffiths & $\begin{array}{l}\text { Columbus } 2272 \\
\text { Columbus } 2452\end{array}$ & $\begin{array}{l}\text { U.S.A.: Arizona } \\
\text { U.S.A.: Arizona }\end{array}$ \\
\hline Bouteloua eriopoda (Torr.) Torr. & \begin{tabular}{|l} 
Columbus 2267 \\
Columbus 2461 \\
Columbus 280 \\
Herrera \& \\
Siqueiros 1340
\end{tabular} & $\begin{array}{l}\text { U.S.A.: California } \\
\text { U.S.A.: Arizona } \\
\text { México: Chihuahua } \\
\text { México: Chihuahua }\end{array}$ \\
\hline $\begin{array}{l}\text { Bouteloua eriostachya (Swallen) } \\
\text { Reeder }\end{array}$ & Columbus 2843 & México: Coahuila \\
\hline $\begin{array}{l}\text { Bouteloua gracilis (Kunth) } \\
\text { Lag. ex Griffiths }\end{array}$ & \begin{tabular}{|l|} 
Columbus 2460 \\
Columbus 2559 \\
Columbus 2574 \\
Columbus 2603 \\
Columbus 2608 \\
Columbus 2612 \\
Columbus 2640 \\
Columbus 2718 \\
Columbus 2793 \\
Columbus 2804 \\
Columbus 2832 \\
Columbus 2863
\end{tabular} & $\begin{array}{l}\text { U.S.A.: Arizona } \\
\text { México: México } \\
\text { México: Hidalgo } \\
\text { México: San Luis Potosí } \\
\text { México: Aguascalientes } \\
\text { México: Jalisco } \\
\text { México: Puebla } \\
\text { México: Sonora } \\
\text { México: Chihuahua } \\
\text { México: Chihuahua } \\
\text { México: Coahuila } \\
\text { México: Nuevo León }\end{array}$ \\
\hline Bouteloua hirsuta Lag. & \begin{tabular}{|l|} 
Columbus 2342 \\
Columbus 2284 \\
Columbus 2558 \\
Columbus 2611 \\
Columbus 2713 \\
Columbus 2792 \\
Columbus 2808 \\
Columbus 2860 \\
Columbus 2894
\end{tabular} & $\begin{array}{l}\text { México: México } \\
\text { México: Coahuila } \\
\text { México: México } \\
\text { México: Jalisco } \\
\text { México: Sonora } \\
\text { México: Chihuahua } \\
\text { México: Chihuahua } \\
\text { México: Nuevo León } \\
\text { U.S.A.: Texas }\end{array}$ \\
\hline Bouteloua johnstonii Swallen & Columbus 2851 & México: Coahuila \\
\hline $\begin{array}{l}\text { Bouteloua juncea (Desv. ex P. } \\
\text { Beauv.) Hitchc. }\end{array}$ & $\begin{array}{l}\text { Axelrod } 8856 \\
\text { Axelrod } 8862\end{array}$ & $\begin{array}{l}\text { Grenada: St. George } \\
\text { Grenada: St. George }\end{array}$ \\
\hline Bouteloua kayi Warnock & Columbus 2281 & U.S.A.: Texas \\
\hline *Bouteloua media (E. Fourn.) Griffiths & $\begin{array}{l}\text { Columbus } 2420 \\
\text { Columbus } 2632\end{array}$ & $\begin{array}{l}\text { México: Oaxaca } \\
\text { México: Puebla }\end{array}$ \\
\hline $\begin{array}{l}\text { Bouteloua mexicana (Scribn.) } \\
\text { J. T. Columbus }\end{array}$ & Columbus 2398 & México: Guerrero \\
\hline $\begin{array}{l}\text { Bouteloua multifida (Griffiths) } \\
\text { J. T. Columbus }\end{array}$ & Columbus 2617 & México: Oaxaca \\
\hline
\end{tabular}


Appendix. Continuation

\begin{tabular}{|c|c|c|}
\hline Taxon & Collection/Voucher & Origin \\
\hline Bouteloua nervata Swallen & Columbus 2334 & México: Hidalgo \\
\hline Bouteloua parryi (E. Fourn.) & Columbus 2299 & México: Sonora \\
\hline Griffiths & Columbus 2351 & México: Jalisco \\
\hline Bouteloua pectinata Feath. & Columbus 2899 & U.S.A.: Texas \\
\hline *Bouteloua pedicellata Swallen & Columbus 2408 & México: Tlaxcala \\
\hline *Bouteloua purpurea Gould \& & Columbus 2337 & México: México \\
\hline Kapadia & Columbus 2563 & México: México \\
\hline Bouteloua quiriegoensis A. Beetle & $\begin{array}{l}\text { Herrera \& } \\
\text { Siqueiros } 1320\end{array}$ & México: Sonora \\
\hline $\begin{array}{l}\text { Bouteloua radicosa (E. Fourn.) } \\
\text { Griffiths }\end{array}$ & $\begin{array}{l}\text { Columbus } 2341 \\
\text { Columbus } 2462 \\
\text { Columbus } 2714 \\
\text { Columbus } 2872 \\
\text { Herrera \& } \\
\text { Siqueiros } 1300\end{array}$ & $\begin{array}{l}\text { México: México } \\
\text { U.S.A.: Arizona } \\
\text { México: Sonora } \\
\text { México: Tamaulipas } \\
\text { México: Aguascalientes }\end{array}$ \\
\hline Bouteloua ramosa Scribn. ex Vasey & \begin{tabular}{|l|} 
Columbus 2287 \\
Columbus 2290 \\
Columbus 2807 \\
Columbus 2826 \\
Columbus 2835 \\
Columbus 2846
\end{tabular} & $\begin{array}{l}\text { México: Coahuila } \\
\text { México: Chihuahua } \\
\text { México: Chihuahua } \\
\text { México: Chihuahua } \\
\text { México: Coahuila } \\
\text { México: Coahuila }\end{array}$ \\
\hline $\begin{array}{l}\text { Bouteloua reederorum } \mathrm{J} . \mathrm{T} \text {. } \\
\text { Columbus }\end{array}$ & \begin{tabular}{|l|} 
Columbus 2642 \\
Columbus 2648
\end{tabular} & $\begin{array}{l}\text { México: Puebla } \\
\text { México: Puebla }\end{array}$ \\
\hline *Bouteloua reflexa Swallen & $\begin{array}{l}\text { Siqueiros } 4394 \\
\text { Siqueiros } 4401 \\
\text { Siqueiros } 4404 \\
\text { Herrera \& } \\
\text { Siqueiros } 1311\end{array}$ & $\begin{array}{l}\text { México: Sonora } \\
\text { México: Sinaloa } \\
\text { México: Sinaloa } \\
\text { México: Sinaloa }\end{array}$ \\
\hline $\begin{array}{l}\text { Bouteloua repens (Kunth) } \\
\text { Scribn. \& Merr. }\end{array}$ & $\begin{array}{l}\text { Columbus } 2350 \\
\text { Columbus } 2425 \\
\text { Columbus } 2569 \\
\text { Columbus } 2607 \\
\text { Columbus } 2613 \\
\text { Columbus } 2618 \\
\text { Columbus } 2621 \\
\text { Columbus } 2705 \\
\text { Columbus } 2865 \\
\text { Columbus } 2879\end{array}$ & $\begin{array}{l}\text { México: Jalisco } \\
\text { México: Yucatán } \\
\text { México: Querétaro } \\
\text { México: San Luis Potosí } \\
\text { México: Jalisco } \\
\text { México: Jalisco } \\
\text { México: Michoacán } \\
\text { México: Sonora } \\
\text { México: Nuevo León } \\
\text { México: Tamaulipas }\end{array}$ \\
\hline Bouteloua rigidiseta (Steud.) Hitchc. & $\begin{array}{l}\text { Columbus } 2231 \\
\text { Columbus } 2233\end{array}$ & $\begin{array}{l}\text { U.S.A.: Texas } \\
\text { U.S.A.: Texas }\end{array}$ \\
\hline
\end{tabular}


Appendix. Continuation

\begin{tabular}{|c|c|c|}
\hline Taxon & Collection/Voucher & Origin \\
\hline $\begin{array}{l}\text { Bouteloua scabra (Kunth) J. T. } \\
\text { Columbus }\end{array}$ & Columbus 2395 & México: Guerrero \\
\hline Bouteloua scorpioides Lag. & $\begin{array}{l}\text { Columbus } 2200 \\
\text { Columbus } 2344 \\
\text { Columbus } 2547 \\
\text { Columbus } 2635\end{array}$ & $\begin{array}{l}\text { México: Nuevo León } \\
\text { México: México } \\
\text { México: México } \\
\text { México: Puebla }\end{array}$ \\
\hline Bouteloua simplex Lag. & $\begin{array}{l}\text { Columbus } 2554 \\
\text { Columbus } 2570 \\
\text { Columbus } 2615 \\
\text { Columbus } 2643 \\
\text { Columbus } 2798 \\
\text { Columbus } 2854\end{array}$ & $\begin{array}{l}\text { México: México } \\
\text { México: Hidalgo } \\
\text { México: Jalisco } \\
\text { México: Puebla } \\
\text { México: Chihuahua } \\
\text { México: Nuevo León }\end{array}$ \\
\hline *Bouteloua triaena (Trin.) Scribn. & $\begin{array}{l}\text { Columbus } 2338 \\
\text { Columbus } 2357 \\
\text { Columbus } 2566 \\
\text { Columbus } 2649\end{array}$ & $\begin{array}{l}\text { México: México } \\
\text { México: Jalisco } \\
\text { México: Hidalgo } \\
\text { México: Puebla }\end{array}$ \\
\hline $\begin{array}{l}\text { Bouteloua trifida Thurb. ex S. } \\
\text { Watson }\end{array}$ & $\begin{array}{l}\text { Columbus } 2126 \\
\text { Columbus } 2269 \\
\text { Columbus } 2805 \\
\text { Columbus } 2849 \\
\text { Columbus } 2864 \\
\text { Columbus } 2882 \\
\text { Columbus } 2902\end{array}$ & $\begin{array}{l}\text { U.S.A.: Texas } \\
\text { U.S.A.: Arizona } \\
\text { México: Chihuahua } \\
\text { México: Coahuila } \\
\text { México: Nuevo León } \\
\text { México: Tamaulipas } \\
\text { U.S.A.: Texas }\end{array}$ \\
\hline *Bouteloua uniflora Vasey & \begin{tabular}{|l|} 
Columbus 2190 \\
Columbus 2319 \\
Columbus 2833 \\
Columbus 2855 \\
Columbus 2901
\end{tabular} & $\begin{array}{l}\text { México: Coahuila } \\
\text { México: Zacatecas } \\
\text { México: Coahuila } \\
\text { México: Nuevo León } \\
\text { U.S.A.: Texas }\end{array}$ \\
\hline $\begin{array}{l}\text { Bouteloua varia (Swallen) } \\
\text { J. T. Columbus }\end{array}$ & Columbus 2645 & México: Oaxaca \\
\hline $\begin{array}{l}\text { *Bouteloua warnockii Gould \& } \\
\text { Kapadia }\end{array}$ & Columbus 2907 & U.S.A.: Texas \\
\hline Bouteloua williamsii Swallen & Columbus 2353 & México: Jalisco \\
\hline Hilaria cenchroides Kunth & $\begin{array}{l}\text { Columbus } 2605 \\
\text { Columbus } 2571 \\
\text { Columbus } 2654\end{array}$ & $\begin{array}{l}\text { México: San Luis Potosí } \\
\text { México: Hidalgo } \\
\text { México: Hidalgo }\end{array}$ \\
\hline Hilaria ciliata (Scribn.) Nash & Columbus 2599 & México: San Luis Potosí \\
\hline Pleuraphis mutica Buckley & \begin{tabular}{|l|} 
Columbus 2803 \\
Columbus 2810
\end{tabular} & $\begin{array}{l}\text { México: Chihuahua } \\
\text { México: Chihuahua }\end{array}$ \\
\hline
\end{tabular}

